Journal of The Faculty of Science and Technology (JFST)

http://journal.oiu.edu.sd/index.php/JFST

https://doi.org/10.52981/jfst.vi7.967

ISSN: 1858 - 6007

مجلة العلوم و الثقانة - جامعة أم درمان الإسلامية ـ وزارة التعليم العالي و البحث العلمي ـ السودان

Research article

JFST Issue No. 7 (2020) 145 - 154

\title{
Chemical Profile and Proximate and Elemental Composition of Ocimum basilicum Grown in Sudan
}

\author{
Ahmed Ali Mustafa*, Hatil Hashim El-Kamali and Adam Mohammed Ahmed \\ Bashir \\ Department of Botany, Faculty of Science and Technology, Omdurman Islamic \\ University, \\ P.O. Box\#382, Omdurman, Sudan. \\ E-mail corresponding author:ahmad.ali11526@gmail.com,
}

\begin{abstract}
:
This study aimed to investigate the chemical profile, proximate and elemental composition of leaves and flowers of Ocimum basilicum grown in Sudan. Gas Chromatography-Mass Spectrometer (GC-MS) was used for the analysis of the n-hexane extracts. Results showed that fifty six compounds were detected from the aerial part of the plant. Most of the identified compounds were terpenoids. Monoterpenes represented 47.19\% of the n-hexane extract while sesquiterpenes were $32.51 \%$. The major compounds were linalool $(18.16 \%)$, methyl eugenol (16.18\%), $\alpha$-terpineol (10.02\%), and Eucalyptol (8.51\%) respectively. Chemical proximate analysis was carried using standard analytical methods. Results showed that the plant was rich in moisture content, total ash, crude fiber and fiber protein. Elemental analysis was performed using the Atomic Absorption Spectrometer and flame emission for the detection of $\mathrm{Ca}, \mathrm{Fe}, \mathrm{Na}, \mathrm{K}, \mathrm{Mg}, \mathrm{Pb}$ and $\mathrm{Mn}$. Results demonstrated higher calcium and potassium contents. In conclusion $O$. basilicum grown in Sudan was a good source of food and therapeutic agents which could be of use in food and pharmaceutical industries.
\end{abstract}

Keywords: Ocimum basilicum; GC/MS; proximate composition; Sudan.

\section{Introduction}

Medicinal plants are rich in secondary metabolites and essential oils of therapeutic importance. The important advantages claimed for therapeutic uses of medicinal plants in various ailments are their safety besides being economical, effective and their easy availability. Because of these advantages medicinal plants have been widely used by traditional medical practitioners in their day to day practice (Ramesh and Satakopan, 2010).

The flora of Sudan consists of 3137 documented species of flowering plants belonging to 170 families and 1280 genera (Khalid et al., 2012). It is estimated that $15 \%$ of these plants are endemic to Sudan. The intersection of cultures and the unique geographical position of 
Sudan hold great potential for research in many fields, the most important of which is medicinal and aromatic plants. The diversity of climates in Sudan results in a rich variety of flora species corresponding to the wide range of ecological habitats and vegetation zones. Though not yet investigated systematically in depth, there are clues in literature about the bio-activity of many Sudanese medicinal plants and their chemical constituents (Ahmed et al., 2010).

The family Lamiaceae (Labiatae) is a large family, comprising about 200 genera and 3,200 species which are widely distributed almost all over the temperate and tropical regions, but centered in the Mediterranean region (Pandey, 2004 and Kumars, 2009). The plants in this family are mostly annual or perennial herbs. They have been reported to have exceptionally high content of $\beta$-carotene, and luteinzeaxanthin. The genus Ocimum (Lamiaceae) comprises 160 species and is found throughout the tropical and sub-tropical regions of the world (Mustafa and El kamali, 2019). O. basilicum. (Commonlyknown in Sudan as Rehan) is native to Africa, Asia and Pacific Island. Ocimum basilicum is an important medicinal plant and a culinary herb that is said to contain several antioxidant compounds and displayed important effects at cellular level, including the platelet anti-aggregate property and inhibitory activity against HIV-1 reverse transcriptase (Amin et al., 2004).

This study aimed to investigate the chemical profile, proximate composition and elemental composition of leaves and flowers of Ocimum basilicum grown in Sudan.

\section{Material and Methods}

\subsection{Plant Material:}

Leaves and flowers of $O$. basilicum., were collected in April 2018 from Karkog region, in Sinnar State, Sudan. The plant species was taxonomically identified by Prof. Maha Kordofani University Khartoum, Department of Botany. The plant was washed thoroughly under running water to remove contamination and was shade dried with active ventilation at ambient temperature for 5 days; the dried leaves and flowers were to fine powder using pistil and mortar.

\section{Preparation of extracts:}

Two hundred grams of aerial parts was extracted by maceration over night in n-hexane. After 3 days it was filtered using filter paper to dryness by evaporating at room temperature. Finally the extract was weighed and stored in cap tight round until use.

\subsection{Gas Chromatography Mass Spectrometer (GC/MS):}

The constituents of the n-hexane extract was characterized and identified by GC/MS. GC/MS analysis were performed on a Shimadzu GC/MS-QP2010A system in ET mode (70ev) equipped with a split splitters injector $\left(250^{\circ} \mathrm{C}\right)$, at split ratio of $5 / 50$ using DB5MSColumn (30 $\mathrm{m}$ x 0.25mm id, film thickness: 0002E25 miss J and W scientific, fulsome, $\mathrm{CA}, \mathrm{WA})$. Injection volume was 1 misarlitre and electronic pressure programming was used 
to maintain a constant flame $(0.67 \mathrm{ml} / \mathrm{mins})$ of the Helium carrier gas. The even temperature was programmed from $150^{\circ} \mathrm{C}(4 \mathrm{mins})$ to $320^{\circ} \mathrm{Cat}$ a rate of $2 \mathrm{c} / \mathrm{mins}$ and held at than temperature $200^{\circ} \mathrm{Cand}$ interface temperature $250^{\circ} \mathrm{C}$. The relative approach percentage of each co-compound was determined by area. Components identification was carried out using the NIST 147 and NIST 27 libraries.

\subsection{Proximate Composition:}

Proximate composition was determined using the method described by AOAC (2004). Samples of $O$. basilicum were estimated for their moisture content, total ash, crude fibre and crude proteins.

\subsection{Elemental composition:}

The elements $\mathrm{Na}$ and $\mathrm{K}$ were determined using flame emission photometer. The principle of this procedure relies on the fact that excitation of a metal in a flame gives rise to the emission of characteristics color. The intensity of the colour emitted by the excitation of any given atom is a property of the specific element and the concentration of that element while others elements ( $\mathrm{Ca}, \mathrm{Fe}, \mathrm{Pb}, \mathrm{Mn}$ and $\mathrm{Zn}$ ) were analyzed by Atomic Absorption Spectrometer (AAS). The principle of this procedure relies on the absorption property of the elements. The vapors of the elements containing free atoms absorbs light having wave length as that which the atoms of the elements are capable of emitting.

\section{4-Result and discussion}

\subsection{Gas Gromatography Mass Spectrometer (GC/MS) of Ocimum basilicum:}

$\mathrm{N}$-Hexane extract of $O$. basilicum aerial parts was analyzedby GC/MS and results are presented in Tables 1. A total of 56 compounds were identified with 18 compounds belonging to monoterpenes followed by 15 compounds as sesquiterpenes, 5 compounds as fatty acids and 4 compounds as alcohols. Phenyl propene, cyclic diterpene alcohol and esters were represented by 2 compounds each while other classes including ketone, alkene, aromatic amine, carbonate, aldehyde and carbonate were represented by only compound each (Table 2).

\subsection{Proximate analysis:}

Results of proximate composition of the flowers and leaves of $O$. basilicum are presented in Table 3. Leaves have more moisture content $(6.88 \pm 0.16 \%)$ than the flowers $(5.55 \pm 0.07 \%)$. This indicates that the leave cannot be stored favorably for a long period of time. The stability and susceptibility of microbial contamination of plant material is determined by its moisture content (Scott, 1980). The ash content, which is a reflection of its mineral content, of the leaves $(15.69 \pm 0.04 \%)$ concentrated more minerals than the flowers $(8.81 \pm 0.1 \%)$. On the other hand, the flowers have more crude fibre content $(32.85 \pm 0.05 \%)$ than the leaves $(11.51 \pm 0.12 \%)$. Crude fibre aids digestion and reduces the accumulation of carcinogen in the body (Robinson, 1978). Determination of crude protein 
composition shows that the leaves contain higher protein level $(18.52 \pm 0.13 \%)$ than the flowers $(11.52 \pm 0.13 \%)$. The basic function of protein in nutrition is to supply adequate amounts of required amino acids (Pugalenthi et al., 2004). Protein deficiency causes growth retardation, muscle wasting, and abnormal swelling of the belly and collection of fluids in the body (Zarkada and Voldeng, 1997).

\subsection{Elemental analysis:}

The concentrations of some macro and microelements were determined in samples obtained from the $O$. basilicum, using Atomic absorption (Table 4). Results showed that calcium content was $67.74 \mathrm{mg} / 100 \mathrm{~g}$, iron $1.052 \mathrm{mg} / 100 \mathrm{~g}$, sodium $1.189 \mathrm{mg} / 100 \mathrm{~g}$, potassium $15.600 \mathrm{mg} / 100 \mathrm{~g}$, manganese $0.071 \mathrm{mg} / 100 \mathrm{~g}$, zinc $0.183 \mathrm{mg} / 100 \mathrm{~g}$, Pb was not detected. From this results it could be conclude that calcium was the most abundant element in O. basilicum. Calcium is required in the body for human growth of bones and teeth. It is an important mineral required for bone formation and neurological function of the body. The recommended daily calcium allowance for children and adult is $360-1200 \mathrm{mg} / 100 \mathrm{~g}$ (Robinson, 1978). Potassium was also found in relatively high amount. Potassium is needed for growth and transmission of the nervous system to transmit messages as well as regulating the contractions of muscles (Sale and Maji, 2006). Calcium (Ca) and potassium (K) are reported to be responsible for the repair of worn out cells, strong bones and teeth, building of red blood cells and for body mechanisms (Amokaha et al., 2002). Also, Ca and $\mathrm{K}$ are essential for disease prevention and control and may therefore contribute to the medicinal influences of the plant (Aliyu et al., 2008).

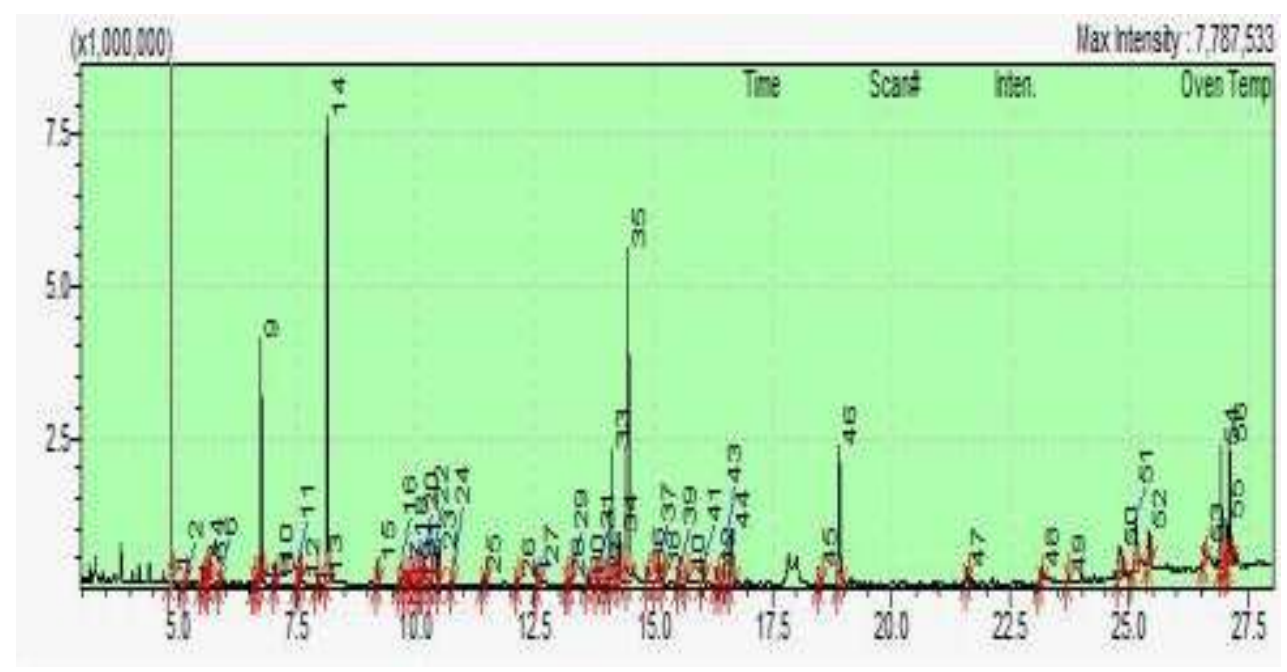

Figure 1.Gas chromatogram of n-hexane extract of Ocimum basilicum aerial parts 
Table 1. Chemical composition of n-hexane extract ofOcimum basilicum aerial parts

\begin{tabular}{|c|c|c|c|c|c|}
\hline No & Compound & RT & $\%$ & Formula & Class type \\
\hline 1 & $\alpha$-pinene & 4.855 & 0.34 & $\mathrm{C}_{10} \mathrm{H}_{16}$ & MH \\
\hline 2 & Camphene & 5.141 & 0.06 & $\mathrm{C}_{10} \mathrm{H}_{16}$ & MH \\
\hline 3 & 3-Hexen-2-one & 5.511 & 0.71 & $\mathrm{C}_{6} \mathrm{H}_{10} \mathrm{O}$ & Ketone \\
\hline 4 & Sabinene & 5.586 & 0.37 & $\mathrm{C}_{10} \mathrm{H}_{16}$ & MH \\
\hline 5 & (-)- $\beta$-pinene & 5.668 & 0.73 & $\mathrm{C}_{10} \mathrm{H}_{16}$ & MH \\
\hline 6 & $\beta$-myrcene & 5.875 & 0.28 & $\mathrm{C}_{10} \mathrm{H}_{16}$ & MH \\
\hline 7 & $\begin{array}{ll}\text { 3-Pyridine } & \text { carboxaaldehyde,o- } \\
\text { acetyloxime } & \end{array}$ & 6.593 & 0.04 & $\mathrm{C}_{8} \mathrm{H}_{8} \mathrm{~N}_{2} \mathrm{O}_{2}$ & Aromatic Amine \\
\hline 8 & D-Linanene & 6.677 & 0.32 & $\mathrm{C}_{10} \mathrm{H}_{16}$ & MH \\
\hline 9 & Eucalyptol & 6.749 & 8.51 & $\mathrm{C}_{10} \mathrm{H}_{18} \mathrm{O}$ & $\mathrm{OM}$ \\
\hline 10 & Cis-ocimene- $\beta$-ocimene & 7.035 & 0.75 & $\mathrm{C}_{10} \mathrm{H}_{16}$ & MH \\
\hline 11 & $\begin{array}{l}\text { Cis-4-thujanol;cis-sabinene } \\
\text { hydrate }\end{array}$ & 7.508 & 0.92 & $\mathrm{C}_{10} \mathrm{H}_{18} \mathrm{O}$ & OM \\
\hline 12 & $\alpha$-methyl- $\alpha$-\{4-methyl-3-penten- & 7.594 & 0.16 & $\mathrm{C}_{10} \mathrm{H}_{18} \mathrm{O}_{2}$ & Alkene \\
\hline 13 & $\begin{array}{l}\text { Ethyl 2-(5-methyl-5-vinyl } \\
\text { tetrahydro-furan-2-yl) propan-2-yl } \\
\text { carbonate }\end{array}$ & 7.927 & 0.28 & $\mathrm{C}_{13} \mathrm{H}_{22} \mathrm{O}_{4}$ & Salt carbonate \\
\hline 14 & Linalool & 8.146 & 18.61 & $\mathrm{C}_{10} \mathrm{H}_{18} \mathrm{O}$ & $\mathrm{OM}$ \\
\hline 15 & (+)-2-Bornanone & 9.194 & 0.91 & $\mathrm{C}_{10} \mathrm{H}_{16} \mathrm{O}$ & $\mathrm{OM}$ \\
\hline 16 & L- $\alpha$-terpineol & 9.654 & 0.41 & $\mathrm{C}_{10} \mathrm{H}_{18} \mathrm{O}$ & $\mathrm{OM}$ \\
\hline 17 & Epoxylinalol & 9.774 & 0.05 & $\mathrm{C}_{10} \mathrm{H}_{18} \mathrm{O}_{2}$ & FA \\
\hline 18 & Terpinen-4-ol & 9.873 & 0.29 & $\mathrm{C}_{10} \mathrm{H}_{18} \mathrm{O}$ & $\mathrm{OM}$ \\
\hline 19 & 1-undecanol & 10.025 & 0.09 & $\mathrm{C}_{12} \mathrm{H}_{26} \mathrm{O}$ & Alcohol \\
\hline 20 & $\begin{array}{l}\text { 3,7-octadiene-2,6-diol,2,6- } \\
\text { dimethyl- }\end{array}$ & 10.090 & 0.09 & $\mathrm{C}_{10} \mathrm{H}_{18} \mathrm{O}_{2}$ & Alcohol \\
\hline
\end{tabular}




\begin{tabular}{|c|c|c|c|c|c|}
\hline 21 & $\alpha$-terpineol & 10.156 & 10.02 & $\mathrm{C}_{10} \mathrm{H}_{18} \mathrm{O}$ & $\mathrm{OM}$ \\
\hline 22 & Estragole & 10.299 & 0.13 & $\mathrm{C}_{10} \mathrm{H}_{12} \mathrm{O}$ & $\mathrm{OM}$ \\
\hline 23 & Octyl acetate & 10.466 & 1.26 & $\mathrm{C}_{10} \mathrm{H}_{20} \mathrm{O}_{2}$ & FA \\
\hline 24 & Fenchyl acetate & 10.741 & 0.07 & $\mathrm{C}_{12} \mathrm{H}_{20} \mathrm{O}_{2}$ & FA \\
\hline 25 & Geranial & 11.429 & 0.61 & $\mathrm{C}_{10} \mathrm{H}_{18} \mathrm{O}$ & $\mathrm{OM}$ \\
\hline 26 & Bornyl acetate & 12.128 & 0.32 & $\mathrm{C}_{12} \mathrm{H}_{20} \mathrm{O}_{2}$ & Carboxylic Acid \\
\hline 27 & Cinnamaldehyde,(E)- & 12.546 & 1.13 & $\mathrm{C}_{9} \mathrm{H}_{8} \mathrm{O}$ & Aldehyde \\
\hline 28 & $\beta$-elemene & 13.173 & 0.26 & $\mathrm{C}_{15} \mathrm{H}_{24}$ & SH \\
\hline 29 & 2-Hydroxycineol & 13.248 & 0.07 & $\mathrm{C}_{10} \mathrm{H}_{18} \mathrm{O}_{2}$ & Other \\
\hline 30 & allylguaiacol-3 & 13.606 & 0.49 & $\mathrm{C}_{10} \mathrm{H}_{12} \mathrm{O}_{2}$ & Alcohol \\
\hline 31 & $\begin{array}{l}\text { (E)-2,6-dimethylocta-2,7-diene- } \\
\text { 1,6-diol }\end{array}$ & 13.815 & 0.27 & $\mathrm{C}_{10} \mathrm{H}_{18} \mathrm{O}_{2}$ & Alcohol \\
\hline 32 & Copaene & 13.976 & 0.08 & $\mathrm{C}_{15} \mathrm{H}_{24} \mathrm{O}_{2}$ & SH \\
\hline 33 & $\begin{array}{l}\text { Methyl cinnamate(cinnamic acid } \\
\text { ME) }\end{array}$ & 14.114 & 7.07 & $\mathrm{C}_{10} \mathrm{H}_{10} \mathrm{O}_{2}$ & Ester \\
\hline 34 & Levo- $\beta$-elemene & 14.269 & 1.82 & $\mathrm{C}_{15} \mathrm{H}_{24}$ & SH \\
\hline 35 & Methyl eugenol & 14.464 & 16.18 & $\mathrm{C}_{11} \mathrm{H}_{14} \mathrm{O}_{2}$ & SH \\
\hline 36 & Caryophyllene & 14.873 & 0.54 & $\mathrm{C}_{15} \mathrm{H}_{24}$ & SH \\
\hline 37 & $\alpha$-Bergamotene & 15.085 & 1.02 & $\mathrm{C}_{15} \mathrm{H}_{24}$ & SH \\
\hline 38 & $\alpha \alpha$-guaiene & 15.177 & 0.45 & $\mathrm{C}_{15} \mathrm{H}_{24}$ & SH \\
\hline 39 & Humulene & 15.529 & 0.45 & $\mathrm{C}_{15} \mathrm{H}_{24}$ & SH \\
\hline 40 & $\beta$-Cubebene & 15.694 & 0.30 & $\overline{\mathrm{C}_{15} \mathrm{H}_{24}}$ & $\begin{array}{c}\mathrm{SH} \\
\mathrm{SH}\end{array}$ \\
\hline 41 & Germacrene D & 16.039 & 0.81 & $\mathrm{C}_{15} \mathrm{H}_{24}$ & SH \\
\hline 42 & Germacrene B & 16.333 & 0.63 & $\mathrm{C}_{15} \mathrm{H}_{24}$ & SH \\
\hline 43 & $\alpha$-bulnesene & 16.473 & 0.67 & $\mathrm{C}_{15} \mathrm{H}_{24}$ & SH \\
\hline 44 & $\gamma$-muurolene & 16.630 & 2.28 & $\mathrm{C}_{15} \mathrm{H}_{24}$ & $\begin{array}{c}\mathrm{SH} \\
\mathrm{SH}\end{array}$ \\
\hline
\end{tabular}




\begin{tabular}{|l|l|l|l|c||c|}
\hline \hline 45 & Cubenol & 18.473 & 0.78 & $\mathrm{C}_{15} \mathrm{H}_{26} \mathrm{O}$ & OS \\
\hline 46 & Cadinol & 18.901 & 6.24 & $\mathrm{C}_{15} \mathrm{H}_{26} \mathrm{O}$ & OS \\
\hline 47 & $\begin{array}{l}3,7,11,15 \text {-tetra-methyl-2- } \\
\text { hxadecen-1-ol }\end{array}$ & 21.578 & 0.48 & $\mathrm{C}_{20} \mathrm{H}_{40} \mathrm{O}$ & Diterpene \\
\hline \hline 48 & Palmitic acid & 23.141 & 0.83 & $\mathrm{C}_{16} \mathrm{H}_{32} \mathrm{O}_{2}$ & FA \\
\hline \hline 49 & Carene & 23.710 & 0.23 & $\mathrm{C}_{10} \mathrm{H}_{16}$ & MH \\
\hline 50 & Phytol & 24.799 & 2.49 & $\mathrm{C}_{20} \mathrm{H}_{40} \mathrm{O}$ & Diterpene \\
\hline 51 & Dihydrocarveol & 25.131 & 3.70 & $\mathrm{C}_{10} \mathrm{H}_{18} \mathrm{O}$ & OM \\
\hline 52 & Linalyl butyrate & 26.596 & 1.09 & $\mathrm{C}_{18} \mathrm{H}_{20} \mathrm{O}_{2}$ & FA \\
\hline \hline 53 & $\begin{array}{l}\text { Trans-cinnamic } \\
\text { bengyldimethylsilyl ester }\end{array}$ & & & & \\
\hline \hline 54 & Isosafrole & 26.922 & 4.50 & $\mathrm{C}_{10} \mathrm{H}_{10} \mathrm{O}_{2}$ & Phenyl propene \\
\hline 55 & Safrole & 27.108 & 4.39 & $\mathrm{C}_{12} \mathrm{H}_{14} \mathrm{O}_{4}$ & Phenyl propene \\
\hline \hline 56 & Di methyl 2-phenyl succinate & & & \\
\hline
\end{tabular}

$\mathrm{MH}=$ monoterpene hydrocarbon; $\mathrm{OM}=$ oxygenated monoterpene; $\mathrm{FA}=$ fatty acid; $\mathrm{SH}=$ sesquiterpene hydrocarbon; $\mathrm{OS}=$ oxygenated sesquiterpene.

Table 2. Statistics chemical classes of n-hexane extract of $O$. basilicum:

\begin{tabular}{|l||c||c|}
\hline Compounds & No.of Compounds & Concentration \% \\
\hline \hline Total monoterpene & 18 & 47.19 \\
\hline \hline Total sequiterpene & 15 & 32.51 \\
\hline Phenyl propene & 2 & 6.26 \\
\hline \hline Cyclic diterpene alcohol & 2 & 2.62 \\
\hline Fatty acids & 5 & 3.46 \\
\hline Ketone & 1 & 0.71 \\
\hline \hline Esters & 2 & 8.7 \\
\hline
\end{tabular}




\begin{tabular}{|l|c|c|}
\hline Alcohols & 4 & 0.94 \\
\hline Alkene & 1 & 0.16 \\
\hline \hline Aromatic amine & 1 & 0.04 \\
\hline Carbonate & 1 & 0.28 \\
\hline Aldehyde & 1 & 1.13 \\
\hline Carbonate & 1 & 0.28 \\
\hline Other & 2 & 4.46 \\
\hline \hline Total & 56 & 99.98 \\
\hline
\end{tabular}

Table 3.Proximate composition of the flowers and leaves of the Ocimumbasilicum (\%):

\begin{tabular}{|c|c|c|c|l|}
\hline Part used & $\begin{array}{l}\text { Moisture } \\
\text { content }(\%)\end{array}$ & $\begin{array}{c}\text { Total } \\
\text { Ash(\%) }\end{array}$ & Crude Fiber(\%) & $\begin{array}{l}\text { Crude } \\
\text { Protein(\%) }\end{array}$ \\
\hline Flowers & $5.55 \pm 0.07$ & $8.81 \pm 0.1$ & $32.85 \pm 0.05$ & $11.52 \pm 0.13$ \\
\hline Leaves & $6.88 \pm 0.16$ & $15.69 \pm 0.04$ & $11.51 \pm 0.12$ & $18.52 \pm 0.13$ \\
\hline
\end{tabular}

Mean \pm standard deviation of triplicate determinations.

Table 4. Elemental composition (mg/100g) of Ocimum basilicumusing Atomic Absorption Spectrometer (AAS):

\begin{tabular}{|l|c|c|c|c|c|c|c|}
\hline \multirow{3}{*}{ Plant part } & \multicolumn{7}{|c|}{ Concentration (mg/100g } \\
\cline { 2 - 8 } & $\mathrm{Ca}$ & $\mathrm{Fe}$ & $\mathrm{Na}$ & $\mathrm{K}$ & $\mathrm{Pb}$ & $\mathrm{Mn}$ & $\mathrm{Zn}$ \\
\hline Aerial parts & 67.74 & 1.052 & 1.189 & 15.600 & $\mathrm{ND}$ & 0.071 & 0.183 \\
\hline
\end{tabular}

Mean ND= Not Detected

\section{Conclusions}

The findings of this study shows that $O$. basilicum grown in Sudan belongs to the linalool and methyl eugenol richchemotype.The major compounds of the n-hexane extract were linalool (18.16\%), methyl eugenol (16.18\%), $\alpha$-terpineol (10.02\%), and Eucalyptol (8.51). 
Proximate composition revealed that the plant was rich in moisture, crud protein and protein. Whereas determination of element content shows higher calcium and potassium.

\section{References}

Ahmed, H. M., Nour, B. Y.,Mohammed. Y .G. and Khalid, H. S. 2010. Antiplasmodial activity of some medicinal plants used in Sudanese folk-medecine. Environ. Health Insighis. 4: 1-6.

Aliyu, A. B.; Musa, A. M. and Oshaniyi, J.A. 2008. Phytochemical Analysis and Mineral Composition Analysis of Some Medicinal Plants of Northern Nigeria. Nigerian Journal of Pharmaceutical Sciences, 7(1),119.

Amin, I.Y.; Norazaidah, K.I. and Emmy, H. 2004. Antioxidant Activity and Phenolic content in selected vegetables. Food Chemistry, 87(581-586).

Amokaha, R. A; Ubwa, S.T; Otokpa, M. and Shenga, G. 2002. Phytochemical Screening of Danta Stramonium., linn (Solanacease) Seeds. Journal of Chemical Society of Nigeria, 27(1), $105-107$.

AOAC 2004. Association of Official Analytic Chemist Official method of analysis. Washington, D.C.,14th.ed. Math, R. G., Velu, V., Nagender, A., and Rao, D. G. 2004. Effect of frying conditions on moisture, fat, and density of papar. Journal of Food Engineering, 64(4), 429-434.

Khalid, H., Wail, E.A., Haider, A., Till, O. and Thomas, F. 2012. Gems from traditional north-African medicine and aromatic plants from Sudan. Nat prod Bioprospect.2:92-103.

Kumars, S., 2009. A Text book of Plant Taxonomy .Com-pus Books International, New Delhi, p.297-301.

Mustafa AA, El-kamali HH. 2019. Chemical Composition of Ocimum americanum., In Sudan Res Pharm Healt Sci.;5(3):172-178.

Pandey, B.P., 2004. A Text Book of Botany Angiosperms. S. Chand and Company LTD., New Delhi, p. 344-350.

Pugalenthi, M., Vadivel, V., Gurumoorthi, P., and Janard hanan, K. 2004. Comparative nutritional evaluation of little known legumes, Tamarindusindica, Erythrinaindica and Sesbaniabispinosa.Tropical and Subtropical Agroecosystems, 4(3).p107-123.

Ramesh B, Satakopan V N. 2010. In vitro antioxidant activities of Ocimum species: Ocimum basilicumand Ocimum sanctum. Journal of Cell and Tissue Research; 10(1): 214550.

Robinson C.H 1978. Mineral Elements. In: Fundamentals of natural nutrition, New York: mc millionpublication, company Incorporated, third edition.

Sale, J. F. and Maji, J. O. 2006. The Phytochemical and Antimicrobial Screening of HoneyBased (Ilesha Wonder Drug). Proceedings of the 1st National Conference of the Faculty of Natural. 
Scott W.S.1980.Applied statistics. A hand book of Tech nitnes. Berlin, springer Verlag P.707.

Zarkada C.G and Voldeng H.D.1997. Determination of the protein Quality of three new Northern adapted cultivar s of common and micro types soya beans by amino acids analysis. J. Agricultural Food Chemistry 45:1161-1168. 